\title{
Reimagining Black Freedom - Beyond Place and Time
}

\author{
Traci Cook \\ University of Toronto \\ tracicook@mail.utoronto.ca
}

\begin{abstract}
In this article, the writings of three prolific writers, Canadian Katherine McKittrick, CanadianTrinidadian Marlene NourbeSe Philips and American Maya Angelou, intersect at the point of Black liberation and form a singular voice where a reimagined freedom can emerge.

The piece begins with McKittrick's research of Black geographies and what Black freedom as a destination looks like, by way of a fixed Underground Railroad journey to settlements like Ontario's Negro Creek Road. It further interrogates and reverses the power dynamic between the European colonizer and Black settler, by engaging with Philip's novel, Harriet's Daughter. Here, teen protagonist, Margaret, changes the rules of her Underground Railroad game, making it possible for anybody to be a slave. Finally, these ideas are connected to Angelou's autobiographical accounts of racism in the Deep South and her poetic expressions of hope and freedom through her writings, Caged Bird and I Know Why the Caged Bird Sings.
\end{abstract}

Keywords: Freedom, Underground Railroad, Black geographies, segregation, social justice

\section{Introduction}

What is freedom? Is it a place? Is it a specific time or event? Is it a feeling? How and when does one arrive at or attain freedom? These questions are of particular concern to Black people across the diaspora because "freedom" for Black people in its original capitalist construct and practice was designed to be unattainable. As a result of colonization and empire building by Western Europeans in the new world, physical bondage made worse by mental bondage for many, stamped Black, African bodies as the lowest form of sub-human beings. The colonizers deliberately sold, purchased and enslaved Black adults and children as the chattel property to labour on their plantations.

This article supports an understanding of Black freedom as a process rather than a place or time or destination. To do so, the essay engages some works by Katherine McKittrick and Marlene NourbeSe Philip in conversation with Maya Angelou's metaphoric expressions of freedom from the perspectives of the caged bird. By looking first at Katherine McKittrick's work, which proposes that Black geographies and understandings of Black freedom and liberation cannot be perceived as fixed locations and mappable positions with a "use-by" time-stamp and expiration date, the article creates a framework for disassociating freedom with a particular place or space, and rather associating freedom with the journey, the stories and songs and lessons learned that can never be erased or denied. Next, the article turns to the work of Marlene NourbeSe Philip, who reinforces McKittrick's understanding of Black freedom through her interpretation of a non-fixed place and space for interpreting and understanding the experiences

Cultural and Pedagogical Inquiry, Summer 2020, 12(1), pp. 270-277

ISSN 1916-3460 @ 2020 University of Alberta

http://ejournals.library.ualberta.ca/index.php/cpi/index 
and lessons of the Underground Railroad. Finally, the article aligns the concepts and ithoughts shared by these female Canadian researcher-authors with autobiographical writings by American author, Maya Angelou. In her autobiography, Maya Angelou complements these authors' perspectives through her use of metaphor, comparing the day to day existence of the caged bird to her own lived experiences. Through this literary lens and personal accounts, Angelou shows us how enslaved bodies and spirits can ultimately be free.

In her essay "Freedom is a Secret" (McKittrick, 2007), McKittrick asserts that by limiting our knowledge of Black spaces and places to understandings of social, political or cultural events of the day, the continued utility and relevance of Black geographies are quickly rendered null. McKittrick's research supports the thesis that because Eurocentric norms have defined Black spaces and places as fixtures with preset and temporal meanings, the events or outcomes associated with these specific geographies have also become preset and temporal occurrences.

McKittrick examines these concerns through a critical engagement with NourbeSe Philip's novel, Harriet's Daughter. In the novel, Philip narrates the life experiences of Margaret, the teen protagonist who embraces a newfound identity as a leader and risk taker for freedom, as she takes on the name and persona of the nineteenth century American former enslaved woman, Harriet Tubman. Margaret starts her own Underground Railroad game and enlists the help of her classmates and closest friends to enact her game and make the reenactment real and meaningful. Before long, the Underground Railroad game becomes an act of resistance and solidarity as kids of all races, ethnicities, cultures and social-economic classes followed the lead of their young friend.

Alongside this critique, Maya Angelou's life story provides a critical lens for more closely examining the personal journey toward Black freedom. In her poem, Caged Bird, and novel, I Know Why the Caged Bird Sings, Angelou's poetic symbolism and actual literary accounts of her personal journey as a young Black girl trapped in the fixed histories of the segregated South, also reflect the understandings of young Margaret, Philip's protagonist in Harriet's Daughter. Even as young girls coming from different places and spaces in time, they can imagine a life different from the one they're living and they can embrace the journey.

Angelou, through the honesty and vulnerability of her storytelling, puts her life lessons on display, allowing herself to reflect the complexities of a larger story of Blackness. By describing her own tortured childhood and youth, Angelou mirrors a prescription for release from the gilded cage and the guilt of oppression needed to release other Black people from the entrapment of the oppressor's gaze.

\section{McKittrick Analyzes Black Freedom and Black Geographies}

McKittrick points to several such Black Canadian geographies like "Negro Creek Road, Africville (Halifax) and the Durham Road Cemetery" as examples of the memories, histories and lives of Black settlers and residents that outlived their usability for the White land owner, and whose histories were either erased or rewritten to produce a narrative favoring Eurocentric understandings of Canada's settlement history (McKittrick, 2002, p. 29).

McKittrick likewise sees the inherent dangers in romanticizing the post-slave journey to Canada and the Northern United States. Having nostalgic notions of freedom and liberation as

Cultural and Pedagogical Inquiry, Summer 2020, 12(1), pp. 270-277

ISSN 1916-3460 @ 2020 University of Alberta

http://ejournals.library.ualberta.ca/index.php/cpi/index 
simply fixed places and historical events without deeper meanings and implications puts these historic landmarks of freedom and fugitive histories of the escaped slaves in jeopardy. At best, these nostalgic remnants will over time become a distant memory of a moment in time, with little or no relevance for future change or even survival. McKittrick suggests that "fugitive histories underwrite the narrative, allowing us to consider how the Underground Railroad is now bound up in radical geopolitical challenges to slavery, nation, and racial hierarchies" (McKittrick, 2002, p. 104).

This is where McKittrick brings her argument to life by deeply engaging with CanadianTrinidadian author, poet and playwright Marlene NourbeSe Philip's young adult novel, "Harriet's Daughter", published in 1988. In particular, McKittrick draws upon the courage and empathy of the novel's teen protagonist, Margaret, and her clever focus on the future usability of the Underground Railroad.

\section{The Novel: Harriet's Daughter}

In the novel, Margaret searches for a way to save her friend Zulma, their mothers, and herself from a life within the West Indian community of Toronto that at times feels suffocating and without escape. Margaret's creative and imaginative spirit leaves her feeling different from her family and searching for belonging. Her mother, Vashtina (Tina for short), has suppressed the negative childhood messaging she received about her self-image and gendered roles, and has unknowingly passed some of the same messages on to her daughter. Zulma's mother, in a quest for happiness and freedom for herself and her daughter, migrates to Canada from Tobago, only to find herself trapped in an emotionally and physically abusive marriage.

To rescue them all from their present-day constraints, Margaret takes on the name and persona of Harriet, a name given to her by her mother's former employer in homage to Harriet Tubman. Tubman becomes Margaret's historical hero, inspiring her to take charge of her future and empower those closest to her to do the same. Intrigued and inspired by the audacity of Harriet Tubman's many sojourns to help slaves free themselves, Margaret starts the game as a diversion intended to keep her homesick friend, Zulma, from running away to be with her grandma in Tobago. Before long, the Underground Railroad game becomes an enactment of resistance and solidarity.

\section{Poetry Meets Prose: The Caged Bird Sings}

Much like Philip's protagonist Margaret, Maya Angelou, in her novel, I Know Why the Caged Bird Sings, narrates her lived experiences as a Black girl growing up feeling trapped in her skin and enmeshed in generations of emotional trauma. Born Marguerite Johnson, at age three, Angelou and her four-year-old brother, Bailey Jr., travelled by railway by themselves and arrived in Stamps, Arkansas, at the storefront home of their paternal grandmother, Anne Henderson. They came from Long Beach, California, where they had lived before their father and mother, Vivian Baxter, were divorced. The children's closeness in age along with the constant drama of being shipped from coast to coast many times during their young lives, made the sibling relationship between Angelou and her brother Bailey very strong, and their bond of friendship even stronger.

Understanding the complexities of being racialized as Black began for Angelou as a very young child. Her darker skin and long slender boy-like figure were awkward enough, for these 
were considered to be inferior physical attributes where she lived. Seeing her own mother, a lighter-skinned, long-haired shapely woman whose own mother was herself nearly white, Maya was left "dumbstruck":

To describe my mother would be to write about a hurricane in its perfect power. Or the climbing, falling colors of a rainbow... My mother's beauty literally assailed me...I was struck dumb. I knew immediately why she sent me away. She was too beautiful to have children. I had never seen a woman as pretty as she who was called "Mother." Bailey, on his part, fell instantly and forever in love...he had forgotten the loneliness and the nights we had cried together because we were 'unwanted children'. She was his Mother Dear and I resigned myself to his condition. They were more alike than she and I, or even he and I. They both had physical beauty and personality, so I figured, it figured. (Angelou, 1969, p. 59)

And so, if 'it figured' that these attributes of physical beauty and personality accounted for the privilege that others received, then 'it figured' that Maya was left out, trapped by her lack of everything it took to have value and worth.

Thus, Maya learned early in her childhood that if you are not one of the privileged, who is entitled to love and acceptance and the assurance of walking with the unquestionable benefit of the doubt, then you're one of the oppressed. As one of the oppressed, she was left to her own devices for survival; so, for her, 'it figured' meant that she would be expected to stifle her feelings. At the age of seven, this reality became all too real when "without warning" her father, Bailey Johnson, Sr., decided it was time that Maya and Bailey went to St. Louis to live with their mother and maternal family. It was at this point that Maya recounts, "her world humptieddumptied, never to be put back together again” (Angelou, 1969, p. 53).

Both Maya and her brother were immediately afflicted by the forthcoming change in their circumstances: Bailey's anxiety and fear of losing the privileged love of his revered "Mother Dear" caused him to stutter, and Maya's painful feelings of being unwanted and unloved left her fighting night sweats of horrifying nightmares. While Bailey practiced slowing his speech to hold tight to the favor of privilege and love from his mother, Maya took comfort in sleeping close to her, wedged between her and her boyfriend, Mr. Freeman. Mr. Freeman held her so close when her mother left him in bed with her in the morning. This closeness made Maya feel so protected, like a father would protect his daughter; she even wondered if perhaps, he could be her father. But the father-figure she imagined would not have hurt her like Mr. Freeman eventually did, when he raped her 8-year-old body, threatening to kill her if she screamed and to kill Bailey Jr., the person closest to her in the world, if she told. Not willing to risk the only closeness she had ever felt to her mother and fearing that Mr. Freeman would indeed kill her and Bailey Jr., Maya knew that she had to keep Mr. Freeman's secret. (Angelou, 1969, pp. 71-77)

Maya would soon learn to shield herself from her pain and give herself space to learn more about who she was from the inside out, and not the outside in, the way the world tried to define her. Little by little, Maya began to embrace her differences and find solace in learning more about what made her who she was. Impassioned by Paul Laurence Dunbar's poem, "Sympathy," James Weldon-Johnson's, "The Creation," and the writings of Langston Hughes and W. E. B. DuBois, Maya asked herself where in her world could a Black girl admit that William Shakespeare, a 'white' love, was actually her first love (Angelou, 1969, p. 12). Her 
mother, also a fan of the written and spoken word, would never understand. So, she kept her love affair with Shakespeare a secret from everyone-except Bailey, of course.

Knowing very little and speaking even less was the customary child to adult relationship in the Black segregated South of Angelou's youth. She was naïve, yet unafraid; she knew she had so much to figure out. She didn't even believe for certain that white people were actually real:

In Stamps, segregation was so complete that most Black children didn't really absolutely know what whites looked like. Other than they were different, to be dreaded, and in that dread was included the hostility of the powerless against the powerful, the poor against the rich, the worker against the worked for and the ragged against the well-dressed. (Angelou, 1969, p. 25)

\section{Rules of the Game}

Philip explores her understanding of a reimagined Black freedom by simply changing the rules of a childhood game. Margaret's friends ask her, "Are we only going to have Black slaves?" "Can slaves be white?" "Why not?"

"Hell, anybody can be a slave, and ...freedom is a secret."

"We need slaves and slave owners, and dogs and guides and safe houses and a place called "freedom," Margaret explained. Slavery will be at school and "Freedom" has to be a secret that nobody can know about, except of course, the guides and slaves." (Philip, 2008, pp. 64-65)

And so, the Underground Railroad game begins. Right along the Toronto streets of Christie and St. Clair, Margaret talks her friends into recreating the slave journey from the United States to Canadian freedom.

As part of the escape to freedom game that kids create and play, Philip reverses the power dynamics; those who played slaves and were marginalized and voiceless yesterday, were now Masters, leading, setting rules and determining consequences. Children are thus given the role of (re)imagining the past and (re)constructing a narrative of Black migration and presence in Canada.

Philip's storyline in Harriet's Daughter provides an example of what it looks like to "unbind these radical geopolitical challenges to slavery, nation, and racial hierarchies" (McKittrick, 2007, p. 104). In Margaret's Underground Railroad game, anyone can be a slave, and anyone can be a slave owner; Black and Italian and Irish kids are slaves being chased by Black and Italian and Irish kids who are slave owners. Highlighting this shift flattens the racialized power hierarchy in significant ways; with it comes a sense of accountability for 'the other', especially when at any time 'you' and 'the other' may become one in the same.

\section{Seeing the Underground Railroad as a Figurative Geography}

Margaret reflected, 'Let's see, we've got slaves, slave owners, dogs, safe houses, "freedom," and ...oh, maps. We need maps because we're going to have several different routes to "freedom," just like in the old day" (Philip, 2008, p. 66). 
That Saturday we met at 'slavery' (the school) as usual. I held some papers in my hand; on them I had written the words FREE PAPERS. I gave these to four of the slaves and said, "Ok, you guys are decoys - right. Let the owners and dogs find you, but don't make it look too easy. Run away and sort of hide... when they catch you - present your FREE PAPERS - they have to let you go. That way the others will have a chance to get to freedom" (Philip, 2008, p. 76).

Harriet Tubman became legendary, McKittrick points out, for her courageous creativity, her strategic plans of escape and decoys to avoid entrapment. She planted secret messages to slaves, "hidden in constellations, quilts, landmarks, and in newspaper advertisements," and she coded upcoming getaways in songs like "Steal Away" and "Swing low, Sweet Chariot" (McKittrick, 2007, p. 100). McKittrick goes on to assert that by undoing the past, knowing of the Underground Railroad as a fixed location and path to freedom, its future usability becomes vital to a new way of rethinking the Black journey to freedom as a process of continual becoming.

Before long, Margaret and Zulma and their other classmates, in Harriet's Daughter, are rotating roles as they play the Underground Railroad game. They begin empathizing with each other about the gravity of their conditions as slaves and guides. Some deal easily with the guilt of hunting down the slave enemies who had been their friends just the day before, while others are not able to contain their emotions and succumb to their jealousies and pettiness in pursuit of power. This becomes a pivotal point in the novel, when we also observe the children learning that there must be more than one pathway to freedom. Moreover, they know that even the location of freedom cannot remain the same, nor can it really be a secret, as they realize the struggle to maintain fairness and balance of power even among friends.

The result of this fragmentation unfurls the game. Parents are notified; and although Margaret is not reprimanded at school, her father's reaction is to send her away to Barbados for some GWID: "good West Indian discipline" (Philip, 2008, p. 91). This is an example of when McKittrick steps away from the upper case "Underground Railroad" as a fixed location of freedom and liberation and turns to look at the lower case 'underground' as a more figurative Black geography that reframes our spatial knowledge (McKittrick, 2007, p. 102).

I believe that both McKittrick and Philips would agree that the same courage and empathy that young Margaret embodies when she embraces the spirit of Harriet Tubman and envisions a future usability of the Underground Railroad, is channeled through young Maya Angelou, as she reimagines herself beyond the cage of racism and sexism in the segregated South.

\section{Reimagining Black Freedom: Beyond Place and Time}

When I reflect on the exchange that I imagine Katherine McKittrick, Marlene NourbeSe Philip and Maya Angelou would have about this topic, "Reimaging Black Freedom," I can hear them expressing hopefulness about the future. I expect that they can even imagine themselves as Margaret and Zulma from Philip's novel. I imagine that they would reflect on the stories that Angelou recounted about the Maya of her youth. I expect they would want to support the young girl of Angelou's narrative through the pain she held deep inside and the feelings of abandonment and disquietude that accompanied her physical and social awkwardness. I think they would relish the chance to rewrite the racist and sexist histories of the United States and Canada, from the starfilled skies of Harriet Tubman's Underground Railroad and Margaret's underground journey to freedom on the streets of 1980s Toronto, to the lived experiences that Angelou depicts of young 
Maya in the segregated South. They could, I expect, describe with great detail what a "reimagined freedom" would look like if the secret of freedom were revealed.

Like Marguerite (Maya), Johnson learned over time that whites were for certain, -real, and the painful oppression of her dark-skinned Blackness was just as real; I imagine that Maya Angelou, Katherine McKittrick and Marlene NourbeSe Philip would also consider how this relates to their collective experiences as Black women and how this realization further heightened their understandings of the oppressive pains of Blackness. I suspect that they would relish Angelou's story of how she learned to diminish her pain by reassessing and reimagining the generations of trauma from her past. They would no doubt cling to Angelou's stories of young Maya's pride when her paternal grandmother, Annie Henderson, the only real and true Momma she had ever known, demanded that the white dentist pay for their travel to the Black dentist's office for treatment, when the white dentist refused her Maya care.

I also can imagine that they would feel the same empowerment that Angelou felt when she retold stories about Vivian Baxter, her biological mother. Stories about the way she felt supported by her mother when she stubbornly and defiantly set out to become, and did finally become, the first Negro Conductorette on the San Francisco streetcars. Stories about how Baxter was there for Angelou even through her deepest moments of emotional turmoil, first questioning her femaleness and then using that same courage to define her womanhood, conceiving and bearing a child on her own terms.

McKittrick, Philip and Angelou would perhaps see themselves as the young girls that they once were, already visionary and bringing forth new and innovative ways to ensure that Black people perceive and live out their "ab-so-lute" greatness. They would look admiringly at the Black women in their own research and writings, and in their own lifetimes.

Reading these works by McKittrick, Philip, and Angelou in conversation with one another highlights the importance of Black feminist critical theory and creativity in deconstructing national myths and legends. Their analyses of race, gender and place help to dispel settler narratives of Canada as the Promised Land and the fixed site of freedom, unblemished from racist and sexist norms. They recall the racism and inhumane treatment of Black people throughout the United States, the so-called land of the privileged, the free and the brave. They awaken each of us to the realization that if freedom was once a secret, it is no longer.

"Freedom - the place - is a secret" (Philip, 2008, p. 65). But freedom - the process - has been unveiled and is it available to all. It is a continual process of becoming, a life-long journey, and as a Black being, it is an ongoing struggle. Freedom lives in the lane that Maya Angelou knew well; it was in the same lane that the Black women in her life had spoken of countless times, “'Can't do' and 'Don't Care'. Neither of them has a home, they had told her." This same truth must certainly be relevant when it comes to reimagining Black freedom (Angelou, 1969, p. 261).

Arrival at freedom and liberation is more than the unshackling of physical chains of bondage; rather it is the release of mind, soul and spirit to embrace the hope and possibilities of the unknown. Only through such release can expressions of Blackness be reimagined and freedom be understood as both timeless and beyond boundaries - no longer limited by place or time. 


\section{References}

Angelou, M. (1969). I Know Why the Caged Bird Sings. New York: Random House.

Angelou, M. (1983). “Caged Bird”. New York: Random House.

McKittrick, K. (2002). "Their Blood Is There, and They Can't Throw It Out”: Honouring Black Canadian Geographies. TOPIA: Canadian Journal of Cultural Studies, 7, 27-37.

McKittrick, K., \& Woods, C. (2007). "Freedom is a Secret": The Future Usability of the Underground. In K. McKittrick \& C. Woods (Eds.), Black Geographies and the Politics of Place (pp. 97-114). Toronto: Between the Lines Press.

Philip, M. N. (2008). Harriet's Daughter. Toronto: Women's Press. 